\title{
PROSES PENGAMBILAN KEPUTUSAN KEPALA SEKOLAH TERHADAP PENINGKATAN KINERJA GURU SMP
}

\author{
${ }^{1}$ Murtiningsih dan ${ }^{2}$ Bukman Lian \\ ${ }^{1}$ Guru SMP Negeri 13 Palembang \\ ${ }^{2}$ Dosen Program Studi Magister Manajemen Pendidikan, Universitas PGRI Palembang \\ e-mail: murtiyudhi@gmail.com.
}

\begin{abstract}
Decision is the beginning of an action. Decision making in an educational organization is directly related to the principal. The principal as a manager has an important role in making decisions quickly, accurately and effectively by using data and information for optimal educational environment performance. Decision making conducted by State Secondary School principals 13 Palembang already been running well, this could be seen from the process and stages done by the principal with the decision with the observation, data, planning and registry related to education at school. Then, conduct deliberation with teachers to take a policy, interpersonally approach teachers to organize events, give ideas, engage teachers in training, and supervise as supervisory activities. As outlined in teacher's work assessment, it is useful to improve the potential and performance of teachers, to improve the quality of teaching and learning achievement State Secondary School 13 Palembang
\end{abstract}

Keywords: Principal, Decision-Making, Teachers' Performance, State Secondary School 13 Palembang

\section{PENDAHULUAN}

Sekolah sebagai lembaga formal pendidikan memegang peranan penting dalam meningkatkan kualitas pendidikan melalui pembelajaran untuk menunjang kelancaran jalannya pembangunan di Indonesia secara keseluruhan. Fungsi dan tujuan pendidikan seperti yang termuat dalam Undang-Undang Republik Indonesia Nomor 20 tahun 2003 pasal 3 tentang system pendidikan nasional yaitu "mengembangkan kemampuan dan membentuk watak serta peradaban bangsa yang bermartabat dalam rangka mencerdaskan kehidupan bangsa, bertujuan mengembangkan potensi peserta didik agar menjadi manusia yag beriman dan bertaqwa pada Tuhan Yang
Maha Esa, berakhlak mulia, sehat, berilmu, cakap, kreatif, mandiri dan menjadi warga Negara yang demokratis serta bertanggung jawab. Sumber daya manusia unggul merupakan persyaratan utama bagi terwujudnya bangsa dan negara yang maju. Berapapun besar sumber daya alam (SDA), modal sarana prasarana yang tersedia, pada akhirnya di tangan SDM yang handal sajalah target pembangunan bangsa dan negara dapat dicapai. Dalam perspektif berpikir seperti ini, suatu bangsa tidak dapat mencapai kemajuan tanpa adanya suatu sistem pendidikan yang baik. Pendidikan adalah modal dasar untuk menciptakan SDM yang unggul. Dunia pendidikan yang utama adalah sekolah. 
Sekolah merupakan salah satu lembaga alternatif pelayanan pendidikan. Sekolah sebagai suatu lembaga tentunya memiliki visi, misi, tujuan dan fungsi. Untuk mengemban misi, mewujudkan visi, mencapai tujuan, dan menjalankan fungsinya sekolah memerlukan tenaga profesional, tata kerja organisasi dan sumber-sumber yang mendukung baik finansial maupun non finansial. Guru merupakan salah satu SDM yang berada di sekolah. Kinerja guru di sekolah mempunyai peran penting dalam pencapaian tujuan sekolah.

Mutu pendidikan yang rendah di Indonesia sesuai dari data Balitbang (2003) dari 146.05. SD hanya delapan sekolah yang mendapat pengakuan dunia, dalam katagori The Primary Year Program dari 20.918 SMP di Indonesia ternyata hanya ada delapan sekolah yang mendapat dalam katagori The Middle Years Program (MYP) dan dari 8.036 SMA ternyata hanya tujuh sekolah yang mendapat pengakuan dunia dalam katagori The Diplomat Program (DP) Syarwani Ahmad (2016)

Dalam Undang-Undang Republik Indonesia Nomor 14 Tahun 2005 tentang Guru dan Dosen, pasal 1, ayat (1) menjelaskan bahwa: "Guru adalah pendidik profesional dengan tugas utamanya mendidik, mengajar, membimbing, mengarahkan, melatih, menilai dan mengevaluasi peserta didik pada pendidikan anak usia dini, jalur pendidikan formal, pendidikan dasar, dan pendidikan menengah". Sehingga, guru yang semakin bermutu semakin besar sumbangannya bagi perkembangan diri siswanya dan perkembangan masyarakatnya. Tugas utama guru tersebut merupakan indikator yang akan dijadikan untuk mengukur kinerja guru dalam melaksanakan tugasnya. Menurut Samana (1994:14), guru yang bermutu mampu berperan sebagai pemimpin di antara kelompok siswanya dan juga di antara sesamanya, ia juga mampu berperan sebagai pendukung serta penyebar nilai-nilai luhur yang diyakininya dan sekaligus sebagai teladan bagi siswa serta lingkungan sosialnya, dan secara lebih mendasar guru yang bermutu tersebut juga giat mencari kemajuan dalam peningkatan kecakapan diri dalam karya dan dalam pengabdian sosialnya.

Kepala sekolah adalah pemimpin tertinggi di sekolah walaupun kepemimpinan itu sifatnya situasional, artinya suatu tipe kepemimpinan dapat efektif untuk situasi tertentu dan kurang efektif untuk situasi yang lainnya. Kepemimpinan kepala sekolah sedikit banyak dapat mempengaruhi pendidikan di lingkungan sekolah. Sekolah juga membutuhkan figur seorang pemimpin yang siap bekerja keras untuk dapat memajukan sekolah untuk meningkatkan mutu pendidikan di lingkungan sekolah yang dipimpinnya. 
Kepemimpinan kepala sekolah merupakan cara atau usaha kepala sekolah dalam mempengaruhi, mendorong, membimbing, mengarahkan dan menggerakan guru, siswa, orang tua siswa dan pihak lain yang terkait untuk bekerja/berperan serta guna mecapai tujuan yang ditetapkan. Kemampuan komunikasi interpersonal dan proses pengambilan keputusan yang tepat oleh kepala sekolah akan memberi dampak positif terhadap kinerja guru. Kepala sekolah tidak hanya memberikan pengarahan dan pengawasan saja kepada guru, namun ia juga mampu mengambil keputusan dan mengkomunikasikan hal-hal yang penting guna menciptakan suasana kerja yang kondusif dan dinamis. Suasana yang demikian itu pada giliranya akan mampu mendorong semangat berkarya guru yang pada gilirannya dapat memacu kinerjanya

Berdasarkan paparan tersebut diatas, penelitian ini dilakukan dalam rangka memgungkapkan Pengaruh Proses Pengambilan Keputusan oleh kepala sekolah terhadap peningkatan kinerja guru

\section{PENGAMBILAN KEPUTUSAN}

Pengambilan keputusan adalah tindakan pemilihan alternatif. Hal ini berkaian dengan fungsi manajemen. Misalnya, saat manajer merencanakan, mengelola, mengontrol, mereka membuat keputusan. Hal senada apa yang dikatakan Siswanto (2012) dimana pengembilan keputusan adalah serangkaian aktifitas yang dilakukan oleh seseorang dalam usaha memecahkan masalah yang sedang dihadapi kemudian menetapkan alternative yang dianggap paling rasional dan sesuai dengan lingkungan organisasi, maka pengambilan keputusan dapat dimaknai sebagai intisari dari proses administrasi. Pada hakekatnya pengambilan keputusan adalah suatu pendekatan yang sistematis terhadap hakekat suatu masalah, pengumpulan faktafakta dan data, penentuan yang matang dari alternatif yang dihadapi dan mengambil tindakan yang menurut perhitungan merupakan tindakan yang paling tepat. Pengambilan keputusan merupakan fungsi kepemimpinan yang tidak mudah dilakukan. Oleh sebab itu banyak pemimpin yang menunda untuk melakukan pengambilan keputusan. Bahkan ada pemimpin yang kurang berani mengambil keputusan. Metode pengambilan keputusan dapat dilakukan secara individu, kelompok, tim atau panitia, dewan, komisi, referendum, mengajukan usul tertulis dan lain sebagainya.

Kotter dan Heskett (dalam Tobari 2016) mengatakan bahwa budaya yang kuat dapat menghasilkan efek yang sangat mempengaruhi individu dan kinerja, bahkan dalam lingkungan bersaing pengaruh tersebut dapat lebih besar dari factor-faktor yang lain seperti struktur 
organisasi, alat analisis keuangan dan lainlain.Budaya organisasi yang mudah menyesesuaikan perubahan zaman (adaptif) adalah dapat meningkatkan kinerja. Menurut Huber (dalam Alfonso Sirait 1993) penentuan pilihan mengacu pada kesepakatan kegiatan yang sempit yang melibatkan dalam pemilihansuatu pilihandari seperangkat pilihan alternative.

Pengambilan keputusan yang dilakukan oleh kepala sekolah bertujuan untuk pendapat yang dapat menyelesaikan suatu masalah dengan cara / teknik tertentu agar dapat lebih diterima oleh semua pihak. Masalahnya telebih dahulu harus diketahui dan dirumuskan dengan jelas, sedangkan pemecahannya harus didasarkan pemilihan alternatif terbaik dari alternatif yang ada.

\section{KINERJA GURU}

Menurut Mangkunegara (2001) kinerja adalah hasil kerja secara kualitas dan kuantitas yang dicapai oleh seorang pegawai dalam melaksanakan tugasnya sesuai dengan tanggung jawab yang diberikan kepadanya. Tinggi rendahnya pekerjaan berkaitan erat dengan system pemberian penghargaan yang diterapkan oleh lembaga tempat mereka bekerja yang dapat mempengaruhi tingkat kinerjanya.

Kinerja guru merupakan perwujudan kemampuan dan keterampilan berdasarkan kewenangan yang dimilki dalam tugas pokoknya, yaitu keterampilan mengajar. Perwujudan kemampuan tersebut adalah kegiatan guru dalam proses pembelajaran yaitu merencanakan pembelajaran, melaksanakan kegiatan pembelajaran, dan menilai hasil belajar (Yuliandri dan Kristiawan, 2017).

Berkaitan erat dengan kinerja guru didalam melaksanakan tugas sehari-hari sehingga dalam melaksanakan tugasnya guru yang berkaitan dengan kualitas kerjanya, tanggung jawab, kejujuran, kerjasama.dan prakarsa, kompensasi yang diberikan oleh guru sangat berpengaruh terhadap kepuasan kerja, motivasi kerja dan hasil kerja. Kinerja guru adalah wujud perilaku suatu kegiatan dalam proses pembelajaran yaitu bagaimana seorang guru merencanakan pembelajaran, melaksanakan kegiatan pembelajaran dan menilai hasil belajar (Rusman, 2000). Mengajar merupakan pekerjaan yang menuntut penyesuaian secara terus-menerus, seiring dengan perubahan tuntutan masyarakat yang terus berkembang, sehingga seorang guru harus secara terusmenerus melakukan updating penguasaan materi keilmuannya, dan sekaligus metodenya, sehingga kegiatan pembelajaran yang dilakukannya akan benarbenar kontekstual. Ketiga, mengajar dikatakan sebagai full profession, karena mengajar merupakan suatu profesi, yang anggotanya 
memiliki pengetahuan tertentu dan dapat menerapkan pengetahuannya .

Pada hakekatnya kinerja guru adalah perilaku yang dihasilkan oleh seorang guru dalam melaksanakan tugasnya sebagai pendidik dan pengajar ketika mengajar dikelas sesuai dengan kriteria yang sudah ditetapkan sehingga dapat menjadi guru yang propesionalisme sedangkan guru yang profesional itu sendiri adalah guru yang berkualitas, berkompeten, dan guru yang dikehendaki untuk mendatangkan prestasi belajar serta mampu mempengaruhi proses belajar siswa yang nantinya akan menghasilkan prestasi belajar siswa yang lebih baik. Peraturan Pemerintah Dinas Pendidikan nomor 16 tahun 2007 tentang kompetensi dasar yang harus dimiliki guru 1) kompetensi pedagogik, 2) Kompetensi kepribadian, 3) kompetensi sosial. Untuk menjadi guru yang baik berikut ini yang perlu dicermati, ini sungguh-sungguh nilai yang akan membuat kita bukanlah just ordinary teacher atau agood teacher tapi a great teacher bahwan menjadi $a$ legend yang akan dikenang oleh jiwa-jiwa pembelajar. Danie Ronnie. M (2011).

\section{METODE PENELITIAN}

Penelitian ini termasuk penelitian kualitatif induktif, Patilima (2011) penelitian kualitatif bertolak dari pandangan fenomenologis, yang mana peneliti berusaha memahami arti peristiwa dan kaitan-kaitan terhadap orang biasa dalam situasi tertentu (Kristiawan dan Tobari, 2017).

Pengumpulan data dapat dilakukan dalam berbagai setting, berbagai sumber, dan berbagai cara. Bila dilihat dari setting-nya, data dapat dikelompokan pada setting alamiah (natural setting), dari sumber datanya, maka pengumpulan data dapat menggunakan sumber primer dan sumber sekuder. Sumber primer adalah sumber data yang langsung memberikan data kepada pengumpul data, dan sumber sekunder merupakan sumber yang tidak langsung memberikan data kepada pengumpul data (Sugiyono, 2016).

Dalam penelitian ini peneliti berusaha menggali secara mendalam Pengaruh pengambilan keputusan kepala sekolah terhadap kinerja guru di SMP negeri 13 Palembang, hasil teori-teori tentang proses pengambilan keputusan oleh kepala sekolah terhadap kinerja guru SMP Negeri 13 menjadi data primer penelitian ini.

Obyek pada penelitian ini adalah Kepala sekolah dan guru-guru SMP Negeri 13 Palembang, yang berjumlah selain peneliti melakukan studi dokumen terhadap berita dan literature, peneliti juga melakukan wawancara langsung ke Kepala Sekolah dan guru-guru SMP Negeri 13 Palembang.

Teknik pengumpulan data dapat dilakukan dengan observasi (pengamatan) 
interview (wawancara), kuesioner, dukumentasi, dan gabungan keempatnya. Dalam penelitian kualitatif, pengumpulan data dilakukan pada dilakukan pada natural setting (kondisi yang alamiah), sumber data primer, dan teknik pengumpulan data lebih banyak pada observasi berperan serta (participan observation), wawancara mendalam (in depth interview) dan dokumentasi (Sugiyono, 2016).

Metode pengumpulan data yang digunakan dalam penelitian ini adalah wawancara, observasi, dan studi hasil penelitian di lapangan secara langsung dan dari teori-teori yang terkait dengan proses pengambilan keputusan kepala sekolah terhadap kinerja guru-guru SMP Negeri 13 Palembang.

Observasi merupakan salah satu teknik pengumpulan data yang digunakan dalam penelitian kualitatif (Emir, 2011). Menurut Sutrisno (2004), sebagai metode ilmiah, observasi biasanya diartikan sebagai pengamatan dan pencatatan dengan sistematis atas fenomena-fenomena yang diteliti. Nasution (1988) menyatakan bahwa, observasi adalah dasar semua ilmu pengetahuan. Marshall (Sugiono, 2016) menyatakan bahwa "through observation, the researcher learn about behavior and the meaning attached to those behavior", melalui observasi, peneliti belajar tentang perilaku, dan makna dari perilaku tersebut.
Dalam menganalisis data, peneliti meringkas data dalam bentuk yang mudah dipahami dan ditaksirkan (Sukardi, 2004), menurut Moleong, (2007) aktifitas dalam analisis data kualitatif dilakukan secara interaktif dan berlangsung secara terus menerus pada setiap tahapan penelitian sehingga sampai tuntas dan datanya sudah jenuh.

Penelitian kualitatif telah melakukan analisias data sebelum penelitian memasuki lapangan, analisis dilakukan terhadap data hasil studi pendahuluan, atau data sekunder, yang akan digunakan untuk menentukan fokus penelitian, fokus penelitian ini masih bersifat sementara dan akan berkembang setelah peneliti masuk dan selama di lapangan (Sugiyono, 2016).

\section{HASIL PENELITIAN DAN PEMBAHASAN}

Proses pengambilan keputusan yang dilaksanakan oleh kepala sekolah dilakukan dengan adanya tahap-tahap observasi, pengumpulan data, perencanaan dan mengidentifikasikan masalah yang berkaitan dengan pendidikan disekolah, kemudian melakukan musyawarah diantara guru-guru, untuk mengambil suatu kebijakan atau keputusan, kepala sekolah melakukan kegiatan pendekatan-pendekatan secara interpersonal kepada guru-guru untuk melakukan kegiatan organizing, supervise sebagai kegiatan 
controlling dilakukan oleh kepala sekolah yang dituangkan dalam penilaian kerja guru,untuk meningkatkan potensi guru kepala sekolah mengikut serta guru-guru dalam kegiatan pelatihan dan lomba.(Hasil wawancara dengan kepala SMP Negeri 13 Palembang, Prima Iswarti.S.Pd., M.Si,14 Nopember 2016). Hal ini sesuai apa yang diungkapkan oleh para ahli, yaitu menurut Syarwani (2016) kepala sekolah berfungsi sebagai pendidik, sebagai manajer, sebagai administrasi, dan sebagai supervisor. Tugas kepala sekolah sebagai manejer menurut George R. Terry (Syarwani, 2016) yaitu memiliki fungsi perencanaan (planning), pengorganisasian (organizing), memberi dorongan (actuating), pengawasan (controling).

Menurut Edwin A. Locker dan Associates dalam Syarwani Ahmad (2016) kepala sekolah harus memiliki keterampilan dasar sebagai manajer yaitu, 1) keterampilan teknis (tehnikal skil), 2) ketrampilan hubungan dengan manusia (human relation skill) dan, 3) keterampilan konseptual ketrampilan tehnis berkenaan dengan pengetahuan khusus yang diperlukan untuk melaksanakan funsi-fungsi pokok sebagai Pembina sekolah. Keterampilan tehnis (tehnikal skill) ini meliputi observasi kelas, menetapkan tujuan pengajaran, pengembangan system pengajaran, mendemontrasikan keterampilan pengajaran, melaksanakan penelitian. Keterampilan hubungan kemanusiaan (human relationskill) berkenaan dengan kemampuan kepala sekolah dalam berkerjasama dengan memotivasi guru untuk berkerja secara bersungguh-sungguh. Keterampilan ini merespon perbedaan individu mendengarkan saran dari orang lain, memecahkan konflik dan member contoh yang baik. Sedangkan keterampilan konseptual (konseptual skill) adalah kemampuan kepala sekolah dalam membuat keputusan dan melihat hubungan penting dalam mencapai tujuan. Kegiatan ini juga meliputi prioritas, menganalisis lingkungan, memonitor dan mengontrol aktivitas kelas.

Proses pengambilan keputusan yang dilakukan oleh kepala sekolah harus mendorong untuk terwujudnya visi dan misi sekolah melalui program-program yang terencana dan bertahap. Kepala sekolah sebagai pengambil keputusan harus memiliki dan memahami kompetensi kepala sekolah, 1) Kompetensi keepribadian yakni berakhlak mulia, mengembangkan budaya dan tradisi akhlak muliadan menjadi teladan akhak kepribadian pemimpin. Memilik integritas kepribadian sebagai seorang pemimpin. Memiliki keinginan yang kuat dalam mengembangkan diri sebagai kepala sekolah. Bersikap terbuka dalam melaksanakan tugas pooknya dan fungsi mengendalikan diri dalam menghadapi masalah dalam pekerjaanya 
sebagai kepala sekolah,memiliki bakat dan minat jabatan sebagai kepala sekolah, 2) Kompetensi manajerial menyusun perencanaan sekolah untuk berbagai tingkat sesuai dengan kebutuhan, 3) Memiliki jiwa kewirausahaan yakni menciptakan inovasi yang bergunakan bagi pengembangan sekolah, berkerja keras untuk mencapai keberhasilan sekolah/madrasah sebagai organisasi pembelajaran yang efektif. Memiliki motivasi yang kuat untuk sukses dalam melaksanakan tugas-tugas dan fungsinya sebagai pemimpin pantang menyerah dan selalu mencari solusi terbaik dalam menghadapi sekolah. Memiliki naluri kewirausahaan dalam mengelolah kegiatan produk / jasa sekolah/madrasyah bagi sumber belajar peserta didik, 4) Melaksanakan supervise yakni merencanakan program supervise akademik dalam rangka peningkatan propesionalisme guru, 5) Berkerja sosial, harus berkerjasama dengan pihak lain untuk kepentingan sekolah. Berpartisipsi dalam kegiatan sosial masyarakat. Permen diknas No 28 tahun 2010.

Proses pengambilan keputusan yang dilakukan oleh kepala sekolah yang berpedoman pada kompetensi pendidikan akan menghasilkan sebuah keputusan untuk peningkatan kinerja guru. Sekolah yang diberi otonomi berbasis sekolah dengan maksud kepala sekolah dapat menyusun, melaksanakan dan mengambil keputusan program sekolah yang sesuai dengan masyarakat sekolah. Pengambilan keputusan merupakan cermin dari sikap kepala sekolah sebagai pemimpin hal ini tidak lepas dari kualitas dan kinerja kepala sekolah. Menurut Whitmor (Syarwani, 2016) mengatakan bahwa kinerja merupakan potensi seseorang, suatu perbuatan, suatu prestasi, pameran umum keterampilan.

Kepala sekolah dalam pengambilan keputusan, dilakukan dengan melibatkan langsung dengan wakil kurikulum, guru-guru dalam menentukan kebijakan sekolah yang dipimpinnya, dalam kegiatan proses belajar mengajar guru-guru lebih bervariasi dalam pembelajaran (hasil wawancara dengan guru/M.Sopyan, 13 Nopember 2016). Ketegasan kepala sekolah sebagai seorang manajer dalam proses pengambil keputusan melibatkan semua dewan guru yang ada dilingkungan sekolah, adanya peningkatan kehadiran guru, kerjasama antar guru (hasil wawancara dengan wakil kurikulum Tibian). Kepala sekolah mempunyai keterampilan sosial untuk mengerakan guru-guru, pegawai, steakholder dalam tugas, tanggung jawab, wewenang dalam mengambil keputusan guna kemajuan sekolah (hasil wawancara dengan guru/Vera Afriani, 13 Nopember 2016). Pengetahuan yang dimiliki kepala sekolah yang berupa ide dan gagasan digunakan untuk diimplementasikan kepada guru -guru demi kemajuan sekolah yang dipimpinnya. Kegiatan 
proses pembelajaran lebih bervariasi dan kemampuan penggunaan IT untuk kegiatan pembelajaran dan administrasi (hasil wawancara dengan guru/ Resmiyati, 13 Nopember 2016)

Menurut Syarwani Ahmad (2016), untuk mencapai keberhasilan, kemampuan menghadapi dan mengatasi kesulitan, memerima resiko pemimpin terebut akan mampu memberdayakan dirinya guna mencapai keberhasilan. Pemimpin yang memiliki ketahan malangan yang lebih tinggi akan mempengaruhi dan meningkatkan kinerja, produktifitas, kreatifitas, kesehatan, ketekunan, daya tahan dan validitas yang besar dari pada mereka yang memiliki ketahanmalang yang rendah. Hasil penelitian ini menyimpulkan bahwa kinerja guru SMP Negeri 13 Palembang mengalami peningkatan, dalam proses pembelajaran guru guru lebih bervariasi mengembangkan model-model pembelajaran kurikulum 2013.

\section{KESIMPULAN}

Pengambilan keputusan yang dilakukan kepala sekolah SMP Negeri 13 Palembang sejauh ini sudah sudah berjalan baik hal ini dapat dilihat dari proses dan tahapan -tahapan yang dilakukan oleh kepala sekolah pengambilan keputusan yaitu dengan adanya tahap observasi, pengumpulan data, perencanaan dan mengidentifikasikan masalah yang berkaitan dengan pendidikan di sekolah, kemudian melakukan musyawarah diantara guru-guru, untuk mengambil suatu kebijakan, melakukan kegiatan pendekatan-pendekatan secara interpersonal kepada guru-guru untuk melakukan kegiatan organizing, memberikan gagasan dan ide-ide cemerlang, mengikutsertakan guru-guru dalam kegiatan pelatihan dan lomba, dan supervise sebagai kegiatan controling yang dituangkan dalam penilaian kerja guru, hal ini berguna untuk meningkatkan potensi dan kinerja guru-guru, untuk meningkatkan kualitas belajar mengajar dan prestasi SMP Negeri 13 Palembang, hal ini selaras dengan tugas kepala sekolah sebagai pemimpin yang memiliki fungsi perencanaan (planning), pengorganisasian (organizing), memberi dorongan (actuating), pengawasan (controlling).

\section{DAFTAR PUSTAKA}

Emzir. (2011). Analisa Data: Metodologi Penelitian kualitatif. Jakarta: Rajawali Press.

Kristiawan, M. dan Tobari. (2017). The Characteristics of Full Day School Based Elementary School. Transylvanian Review: Vol XXV, No. 14, 2017

Moleong, Lexy J. (2002). Metodologi Penelitian Kualitatif. Bandung: Remaja Rosdakarya.

Patilima, Hamid. (2011). Metodologi Penelitian Kualitatif. Bandung: CV Alfabeta. 
Peraturan Menteri Pendidikan Nasional No 28 tahun 2010.

Peraturan Pemerintah Dinas Pendidikan nomor 16 tahun 2007 tentang kompetensi dasar yang harus dimiliki guru.

Samana, A. 1994. Profesionalisme Keguruan. Yogyakarta: Kanisius.

Sugiyono. (2016). Metodologi Penelitian Kuantitatif Kualitatif dan R\&D. Bandung: CV Alfabeta.

Sutrisno, Hadi. (2004). Metodologi Reseach Jilid 2. Yogyakarta: Andi Publisher.

Syarwani, Ahmad. (2016). Ketahanmalangan Kepemimpinan Kepala Sekolah. Yogyakarta. Deepublish. Deepublish.
Tobari. (2016). Membangun Budaya Organisasi Pada Instansi Pemerintahan.Yogyakarta.

Undang-Undang Republik Indonesia Nomor 20 tahun 2003 pasal 3 tentang system pendidikan nasional

Undang-Undang Republik Indonesia Nomor 14 Tahun 2005 edisi 2009, Tentang Guru dan Dosen, Bandung, Depdiknas, Citra Umbar.

Yuliandri, J., \& Kristiawan, M. (2017). Peran Kepemimpinan Kepala Sekolah Terhadap Peningkatan Kinerja Guru. Jurnal Dosen Universitas PGRI Palembang. 